\title{
AGONUM SCITULUM DEJEAN, 1828 (COLEOPTERA, CARABIDAE) - NEW DATA ON A RARE CARABID BEETLE SPECIES IN CROATIA
}

\section{Andreja Brigić ${ }^{*}$, Renata Šoštarić ${ }^{2}$, Zorana Sedlar ${ }^{2}$ \& SNJežana VujČić-Karlo ${ }^{3}$}

\author{
${ }^{1}$ Division of Zoology, Department of Biology, Faculty of Science, University of Zagreb, \\ Rooseveltov trg 6, 10000 Zagreb, Croatia (*andreja.brigic@biol.pmf.hr) \\ ${ }^{2}$ Division of Botany, Department of Biology, Faculty of Science, University of Zagreb, \\ Marulićev trg 20/II, 10000 Zagreb, Croatia
}

${ }^{3}$ National Museum Zadar, Natural History Department, Medulićeva 1, 23000 Zadar, Croatia (prirodoslovni.odjel@nmz.hr)

Brigić, A., Šoštarić, R., Sedlar, Z. \& Vujčić-Karlo, S.: Agonum scitulum Dejean, 1828 (Coleoptera, Carabidae) - new data on a rare carabid beetle species in Croatia. Nat. Croat., Vol. 25, No. 2., 279-285, Zagreb, 2016.

The western Palaearctic carabid beetle Agonum scitulum has been found at the fen in Mt Žumberak (NW Croatia). This second Croatian record represents the south westernmost distribution point for this rare species in Europe. Agonum scitulum is an extremely hygrophilous species, recorded on humid alkaline soil in the vicinity of the Jarak Stream, in the successional phase of common reed and willow surrounding the basophilous Jarak fen. During two years of systematic sampling at this locality using different methods only two macropterous specimens of $A$. scitulum were collected with pitfall traps, leading to the conclusion that this species is probably rare in the area.

Keywords: hygrophilous ground beetles, basophilous fen, Mt Žumberak, new record

Brigić, A., Šoštarić, R., Sedlar, Z. \& Vujčić-Karlo, S.: Agonum scitulum Dejean, 1828 (Coleoptera, Carabidae) - novi podaci o rijetkoj vrsti trčka u Hrvatskoj. Nat. Croat., Vol. 25, No. 2., 279-285, Zagreb, 2016.

Agonum scitulum je zapadnopalearktička vrsta zabilježena na bazofilnom cretu Jarak koji se nalazi na području Žumberka (sjeverozapadna Hrvatska). Drugi nalaz u Hrvatskoj predstavlja najjugozapadniju točku rasprostranjenja ove rijetke vrste u Europi. Ova higrofilna vrsta zabilježena je na vlažnom i blago alkaličnom tlu u neposrednoj blizini potoka Jarak, unutar sukcesijskog stadija trske i vrbe koji okružuje cret Jarak. Tijekom dvogodišnjeg sistematičnog sakupljanja različitim metodama na ovom lokalitetu zabilježene su svega dvije makropterne jedinke metodom lovnih posuda, što implicira da je ova vrsta rijetka na istraživanom području.

Ključne riječi: higrofilni trčci, bazofilni cret, Žumberak, novi nalaz

\section{INTRODUCTION}

Agonum scitulum (Dejean, 1828) is a Western Palaearctic species, discontinuously distributed from England to Romania (Löвl \& SMETANa, 2003), including the European part of Russia, where it was recently recorded (Schmidt \& BenedikT, 2010). It is a very rare species both at the range edges (Horvatovich, 1994; Luff, 2007) and in the core area of distribution (Schmidt \& Benedikt, 2010). So far, it is not completely clear whether this 
species extended its range from Atlantic coast to southward and to the east or whether it remained as a glacial relict in southeastern parts of Europe (SсHмIDT \& BENEDIKT, 2010).

In the Western Balkans, this species was recently recorded for Croatia and Slovenia (Schmidt \& BenedikT, 2010), but with no data on habitat description for either country. The first locality in Croatia is located on Ivanščica Mountain near Ivanec, dating back from the beginning of June 2003; leg. Krause, 1 specimen (Schmidt \& Benedikt, 2010). In the past, $A$. scitulum was misidentified as two widespread species $-A$. micans Nicolai, 1822 and A. fuliginosum Panzer, 1809 (Anderson et al., 2000; PAill, 2010; Schmidt \& BENEDIKT, 2010). Both of these widespread species were previously recorded for Croatia (Schlosser-Klekovski, 1877; Bregović, 1985; Drovenik \& Peks, 1999; Bušnja, 2007). However, due to taxonomical uncertainties, these records should be taken with caution.

Overall, data on the ecology of this rare species are scarce. Therefore, the objectives of this paper are: (1) to document the second record of A. scitulum in Croatia and (2) to give further information on its habitat.

\section{MATERIAL AND METHODS}

\section{Study area}

The basophilous fen Jarak ( $\mathrm{N} 45^{\circ} 45^{\prime} 46.44^{\prime \prime}$, E $\left.15^{\circ} 22^{\prime} 1.2^{\prime \prime}\right)$ is located near Sošice village on Žumberak Mountain (Žumberak - Samoborsko gorje Nature Park), in the northwestern mountainous part of Croatia at an altitude of $690 \mathrm{~m}$. It is situated in a gorge whose slopes are overgrown with beech forest (Luzulo luzuloidi - Fagetum Meusel, 1937) on one side and a planted black pine forest (Pinus nigra Arnold) on the other (Fig. 1a). The Jarak fen covers an area of only 1 ha, with the small Jarak Stream running through it.

The fen vegetation belongs to ass. Eriophoro latifolii-Caricetum paniceae Horvat 1962 ex Trinajstić 2002. It is well formed and fen-specific plant species, such as broad-leaved cotton grass (Eriophorum latifolium Hoppe), Host's sedge (Carex hostiana DC.) and greater tussock-sedge (C. paniculata L.), dominate the area. However, the fen is seriously threatened by the aggressive common reed [Phragmites australis (Cav.) Trin. ex Steud.] which is overgrowing the fen from the south side (ŠošTARIć et al., 2012).

The first successional phase of the vegetation (Figure $1 \mathrm{~b}$ ) is composed of dense stands of common reed, grey willow (Salix cinerea L.), purple willow (Salix purpurea L.) and common butterbur [Petasites hybridus (L.) P.Gaertn., B.Mey. and Schreb.]. The second successional phase of the vegetation is represented by young forest-a mixture of willows and different woody and herbaceous species. Common reed, common butterbur, purple willow [Salix purpurea L. (G)] and common aspen [Populus tremula L. (G)] dominate the area. Specific fen plant species were rare at both successional habitats.

The beech forest is situated on a slope west of the fen. Vegetation belongs to ass. Luzulo luzuloidi - Fagetum and it is dominated by European beech (Fagus sylvatica L.). This acidophilous association was characterised by a very poor herbaceous layer and a deep leaf litter layer.

\section{Sampling \& identification}

Sampling was conducted at four habitats: in the fen, in the $1^{\text {st }}$ successional phase of vegetation, in the $2^{\text {nd }}$ successional phase of vegetation and in the beech forest. Agonum scitulum was collected together with other soil arthropods with pitfall traps. Within each 

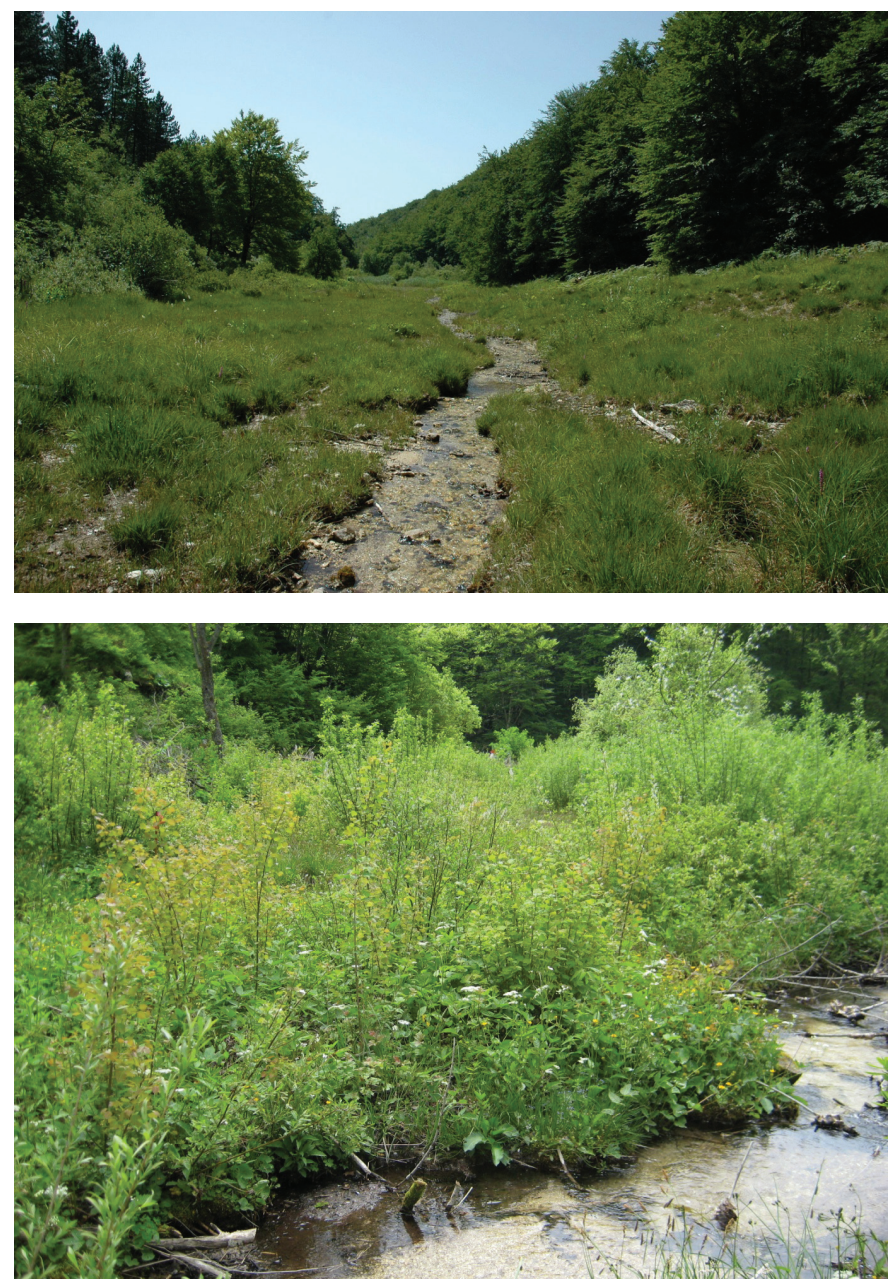

Fig. 1. a) Jarak fen (Žumberak - Samoborsko gorje Nature Park); b) $1^{\text {st }}$ successional phase of vegetation surrounding the fen area.

habitat type 5 pitfall traps were installed, placed $5 \mathrm{~m}$ apart. The traps (polythene cups $8.5 \mathrm{~cm}$ wide and $12.0 \mathrm{~cm}$ deep) were partially filled with saturated salt solution and a drop of neutrally-smelling detergent was added to reduce the surface tension of the liquid. A Styrofoam roof was placed above each trap to protect it from rain. The trapping period spanned two growing seasons (2008-2009), from the end of April to the beginning of December. Samples were collected once a month. In addition, we applied other field sampling methods, e.g. knock-down method, leaf-litter extraction and hand collecting. First two methods were applied 2 times (once in June and September) every growing season, while carabids were hand collected monthly each time in the field.

Specimens of $A$. scitulum were identified according to SCHMIdT in MüLler-MotzFeld (2006). All collected specimens are deposited in the collection of the first author A.B. (Department of Biology, Faculty of Science, Zagreb). 


\section{Vegetation analysis}

Vegetation of the studied area was represented with phytosociological relevés, which were made in accordance with standard Central European methodology (BRAUn-BLANQUET, 1964). Plant nomenclature follows Flora Europaea (Tutin et al., 1964-1980; Tutin et al., 1993).

\section{Soil analysis}

Soil moisture was measured using the gravimetric method (REYNOLDs, 1970), from core samples collected monthly at each sampling site $(\mathrm{d}=10 \mathrm{~cm}, \mathrm{~h}=2 \mathrm{~cm})$. The same soil sample was used to measure $\mathrm{pH}$ in water with a ratio of 1:2.5 (w/v) $(10 \mathrm{~g}$ substrate / $25 \mathrm{~mL} \mathrm{H}_{2} \mathrm{O}$ ) using WTW pH 330i meter. Average values of soil moisture and $\mathrm{pH}$ were calculated.

\section{RESULTS AND DISCUSSION}

Agonum scitulum was collected with pitfall traps in the Jarak fen on June 18, 2009 and July 12, 2009, thus this record in northern Croatia, represents an extension of its distribution range to the southwest (Fig. 2). Both specimens of A. scitulum were found inside the $1^{\text {st }}$ successional phase of common reed and willow that surrounds the fen (Fig. 1b). Vegetation height was around $130 \mathrm{~cm}$. In the $1^{\text {st }}$ successional phase of common reed and willow some parts of the ground were unshaded. Soil was flooded in spring and moist

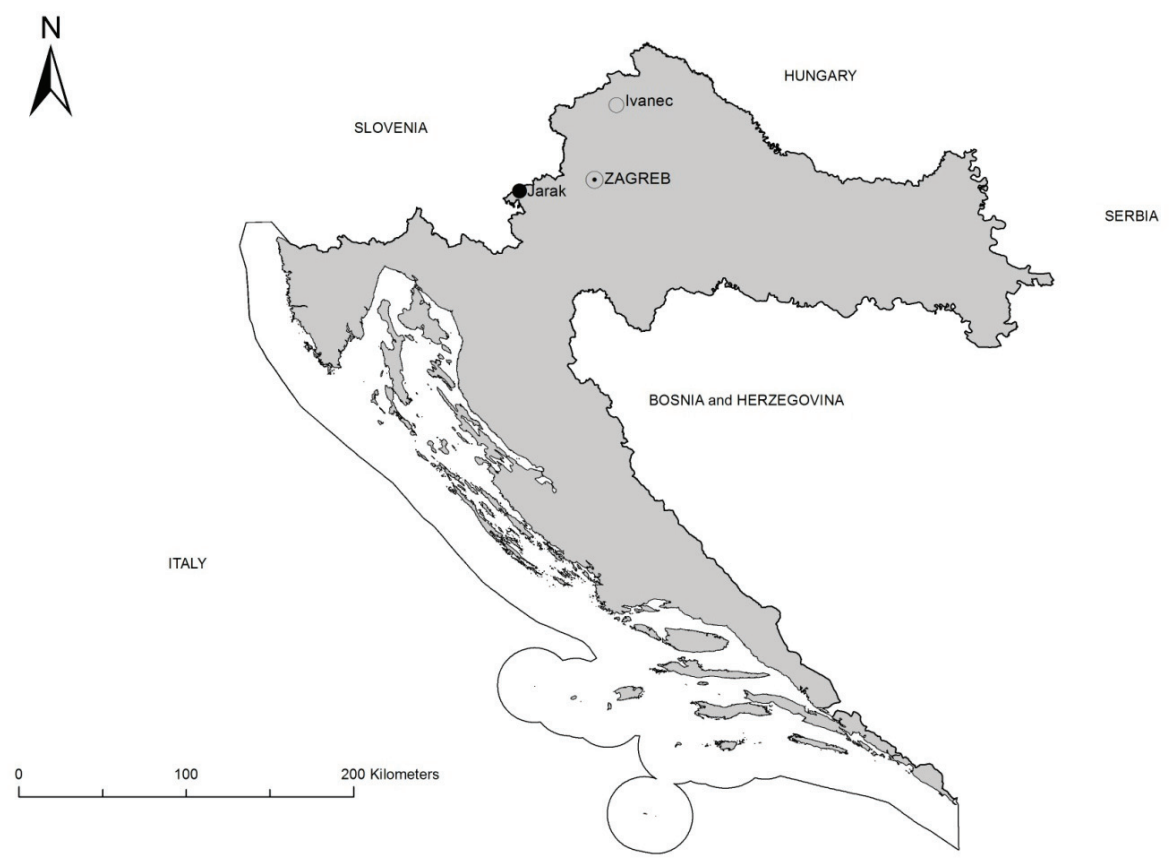

Fig. 2: Distribution of Agonum scitulum Dejean, 1828 in Croatia. Legend: o - finding from Schmidt \& BenediKT, 2010; • - finding from current study. 
through the whole season (season mean \pm SD: $2008-57.71 \% \pm 14.73 ; 2009-49.95 \pm 3.28$ ). Soil $\mathrm{pH}$ was slightly alkaline $(7.42 \pm 0.15)$.

Agonum scitulum was collected in the Žumberak area together with other Agonum species: A. fuliginosum Panzer, 1809; A. hypocrita Apfelbeck, 1904; A. lugens Duftschmid, 1812; A. sexpunctatum Linné, 1758 and A. viduum Panzer, 1796. Most of the species of the genus Agonum are hygrophilous and can be found in the proximity of water (ScHmIDT in Müller-Motzfeld, 2006; Wachmann et al., 1995). Similarly, A. scitulum is an extremely hygrophilous species that has been found along river and stream banks with both sparse and thick vegetation (Assmann, 1991; Косн, 1989; Paill, 2010). Additionally, it occurs in wet shaded meadows, ditches overgrown with Carex sp. and Phragmites sp., fens and carrs (Luff, 2007; Luka et al., 2009; PAILL, 2010). However, this species was not recorded at the other studied peatlands in Croatia (e.g. Dubravica bog, Plaški fen, Đon močvar bog) (BRIGIĆ, unpublished).

During the two consecutive years sampling, A. scitulum was collected only by pitfall traps. However, we did not collect it with other applied sampling techniques. Both collected specimens were macropterous. Low activity density indicates that this species is rather rare in the studied area, which could be related to methodological ambiguities. Agonum scitulum represents a methodological edge species, which is not easily sampled by the method used (sensu stricto Longino et al., 2002). Moreover, PAILL (2010) recently found A. scitulum in higher abundances at several locations in south Austria, but all specimens were hand collected (sampling effort: $20 \mathrm{~m}$ along water margin, in $30 \mathrm{minu}$ tes time). Therefore, it is possible that this species was overlooked in previous studies since most of the ecological studies of carabids in riparian habitats in Croatia were conducted using pitfall traps (Kučınić et al., 1996; Durbešić et al., 1998; Vujčıć-Karlo \& Durbešić, 2004; Vujčić-Karlo, 2006, 2007; TAllósi, 2008; Brigić et al., 2014).

Additionally, riparian habitats and wetlands were less represented in southern Europe in targeted carabid research. Implementation of alternative sampling techniques (frequent hand collecting) in future studies could give further information on this rare species.

\section{Acknowledgements}

This study was supported in part by Žumberak-Samoborsko gorje Nature Park (PI: R. Šoštarić). We would also like to thank to Jelena Bujan for linguistic help.

Received April 28, 2014

\section{REFERENCES}

Anderson, R., McFerran, D. \& Cameron, A., 2000: The Ground Beetles of Northern Ireland. Ulster Museum Dublin. p. 246.

Assmann, T., 1991: Die ripikole Carabidenfauna der Ems zwischen Lingen und dem Dollart. Osnabrücker Naturwissenschaftliche Mitteilungen 17, 95-112.

Braun-Blanquet, J., 1964: Pflanzensoziologie: Grundzüge der Vegetationskunde. Verlag Eugen Ulmer Wien-New York. p. 865.

BREgović, A., 1985: Zbirka karabida Entomološkg odjela Gradskog muzeja Varaždin. Godišnjak Gradskog muzeja Varaždin 7, 221-248.

Brigić, A., Vujčić-Karlo, S., Matoničkin Kepčija, R., Stančić, Z., Alegro, A. \& Ternjej, I., 2014: Taxon specific response of carabids (Coleoptera, Carabidae) and other soil invertebrate taxa on invasive plant Amorpha fruticosa in wetlands. Biological Invasions, DOI 10.1007/s10530-013-0587-8 
Drovenik, B. \& Peкs, H., 1999: Catalogus faune. Carabiden der Balkanländer. Coleoptera Carabidae. Heinz Peks Schwanfeld. p. 103.

Durbešić, P., Krulik, I., Vujčić-Karlo, S., Gjurašin, B., Jalžić, B., Perović, F., Krčmar, S. \& Merdić, E., 1998: Faunističko-ekološka studija člankonožaca (Arthropoda) slatkovodnog dijela ušča Neretve. Hrvatsko ekološko društvo Zagreb. p. 64.

Horvatovich, S., 1994: Small populations of Carabidae and the protection of nature in Hungary. In: Desender, K., Dufrêne, M., Loreau, M., Luff M. L., Maelfait, J-P. (eds.), Carabid beetles: Ecology and Evolution. Kluwer Academic Publisher Dordrech Boston London. p. 313-317.

Косн, K., 1989: Die Käfer Mitteleuropas, Ökologie. Bd 1. Goecke \& Evers Krefeld. p. 440.

Kučinić, M., Perović, F. \& Vujčić-Karlo, S., 1996. Entomološka istraživanja donjeg toka rijeke Neretve. Technical report, Hrvatski prirodoslovni muzej Zagreb. p. 70.

Löbl, I. \& Smetana, A., 2003: Catalogue of Palaearctic Coleoptera. Apollo Books Stenstrup. p. 819.

Longino, J. T., Coddington, J. \& Colwell, R. K., 2002: The ant fauna of a tropical rain forest: estimating species richness three different ways. Ecology 83(3), 689-702.

Luff, M. L., 2007: The Carabidae (ground beetles) of Britain and Ireland, Handbooks for the identification of British Insects. Royal Entomological Society St. Albans. p. 247.

Luka, H., Marggi, W., Huber, C., Gonseth, Y. \& Nagel, P., 2009: Coleoptera, Carabidae: ecology, atlas. Fauna Helvetica, 24. Centre suisse de cartographie de la faune \& Schweizerische Entomologische Gesellschaft Neuchâtel. p. 677.

Paill, W., 2010: Agonum scitulum Dejean, 1828 in Österreich - bisher übersehen oder in Ausbreitung begriffen? (Coleoptera: Carabidae). Beiträge zur Entomofaunistik 11, 79-83.

REYNOLDS, S. G., 1970: The gravimetric method of soil moisture determination I. Journal of Hydrology 11, 258-273.

Schmidt, J. in Müller-Motzfeld, G., 2006: 17. Tribus Platynini Bonelli, 1810. - In: Müller-Motzfeld, G. (Ed.): Die Käfer Mitteleuropas. Vol. 2. Adephaga 1. Carabidae (Laufkäfer). Corrected version of the 2. edition. Elsevier, München: 251-282.

Schmidt, J. \& Benedikt, S., 2010: Zur Verbreitung des Agonum scitulum Dejean, 1828 (Coleoptera, Carabidae). Entomologische Nachrichten und Berichte 54(1), 64-65.

Schlosser-KLekovski, J., 1877: Fauna kornjašah Trojedne kraljevine. I, JAZU Zagreb. p. 342.

Šoštarić, R., SEDlaR, Z. \& MAREKović, S., 2012: An endangered rich fen habitat along the Jarak stream (Nature Park Žumberak-Samoborsko gorje, Croatia). Natura Croatica 21(2): 335-348.

TALLósI, B., 2008: Population-level baseline surveying and preparative investigations for the monitoring of carabid beetles (Coleoptera, Carabidae) in areas along the Drava river and Baranja (Croatia). In: Purger, J. J. (ed.), Biodiversity studies along the Drava River. University of Pécs Pécs. p. 165-220.

Tutin, T. G., Burges N. A., Chater, A. O., Edmondson, J. R., Heywood, V. H., Moore, D. M., Valentine, D. H., Walters, S. M. \& Webb, D. A. (eds.) 1993: Flora Europaea 1. Cambridge University Press Cambridge. p. 629 .

Tutin, T. G., Heywood, V. H., Burges, N. A., Moore, D. M., Valentine, D. H., Walters, S. M. \& Webb, D. A. (eds.) 1964-1980: Flora Europaea 2-5. Cambridge University Press Cambridge.

Vujčić-Karlo, S. \& Durbešrć, P., 2004: Ground beetle (Coleoptera: Carabidae) fauna of two oak woods with two different water balances. Acta Entomologica Slovenica 12, 139-150.

Vujčić-Karlo, S., 2006: Inventarizacija trčaka - Carabidae, strizibuba - Cerambycidae i belegara - Scarabaeidae (kornjaši - Coleoptera) u parku prirode „Telašćica”. Technical report, Narodni muzej Zadar Zadar. p. 1-39.

Vujčić-Karlo, S., 2007: Inventarizacija trčaka (Coleoptera, Carabidae) u Parku prirode Vransko jezero. Technical report, Narodni muzej Zadar Zadar. p. 1-71.

Wachmann, E., Platen, R. \& Brandt, D., 1995: Laufkäfer - Beobachtung, Lebenweise. Naturbuch Verlag Augsburg. p. 295. 


\title{
SUMMARY
}

\section{Agonum scitulum Dejean, 1828 (Coleoptera, Carabidae) - novi podaci o rijetkoj vrsti trčka u Hrvatskoj}

\author{
A. Brigić, R. Šoštarić, Z. Sedlar \& S. Vujčić-Karlo
}

Agonum scitulum je izrazito rijetka vrsta disjunktnog areala. Rasprostranjena je od Engleske pa sve do Rumunjske, uključujući i Europski dio Rusije. Sснмidt \& BENEDiкт (2010) navode kako nije jasno da li je ova vrsta u ekspanziji te se od zapada širi prema istoku ili se radi o vrsti koja je na južnim dijelovima areala ostala kao glacijalni relikt. U prošlosti je vrsta bila zamijenjena s dvama srodnim vrstama A. micans i $A$. fuliginosum (PAILL, 2010), te je moguće kako je rasprostranjenija nego što se misli. Podaci o rasprostranjenju, a posebice ekologiji vrste su malobrojni.

Prije ovog istraživanja, vrsta A. scitulum je zabilježena samo jednom za faunu trčaka Hrvatske, međutim nisu navedeni podaci o staništu na kojem je pronađena (SCHMIDT \& BeNEDICT, 2010). Stoga ovaj nalaz predstavlja drugi nalaz za Hrvatsku i ukazuje na proširenje areala vrste prema jugozapadu. Vrsta je skupljena metodom lovnih posuda tijekom dvogodišnjeg istraživanja na bazofilnom cretu Jarak (Sošice, Park prirode Žumberak-Samoborsko gorje). Istraživanjem su obuhvaćena četiri tipa staništa: cret, prvi sukcesijski stadij, drugi sukcesijski stadij i bukova šuma, a na svakom je postavljeno pet lovnih posuda. Usprkos tome što su u istraživanju obuhvaćeni različiti tipovi staništa i primijenjene različite metode lova, ulovljene su svega dvije jedinke. Obje jedinke ulovljene su u prvom sukcesijskom stadiju creta obraslom trskom i vrbama. Visina vegetacije iznosila je oko $130 \mathrm{~cm}$, tlo je bilo vlažno i blago alkalno.

Vrsta A. scitulum je pronađena u zajednici s drugim vrstama ovog roda: A. fuliginosum, $A$. hypocrita, A. lugens, A. sexpunctatum i $A$. viduum. Zanimljivo je istaknuti kako vrsta nije utvrđena na drugim cretovima u Hrvatskoj (Dubravica, Plaški, Đon močvar) (BRIGić, neobjavljeno). Nalaz potvrđuje prisustvo ove rijetke vrste $A$. scitulum za faunu trčaka Hrvatske. Čini se da A. scitulum predstavlja metodološki rubnu vrstu (sensu stricto LongINo et al., 2002), koja se očito teže lovi metodom lovnih posuda. Naime, PAILL (2010) je nedavno zabilježio vrstu A. scitulum s većim brojem jedinki na nekoliko lokacija u južnoj Austriji, međutim, sve su jedinke sakupljene rukom. Stoga je moguće da je ova vrsta previđena u prijašnjim istraživanjima u Hrvatskoj, jer je većina ekoloških istraživanja vlažnih staništa provedena metodom lovnih posuda (Brigić et al., 2014; Durbešić et al., 1998; Kučinić et al., 1996; Tallósi, 2008; VujČić-Karlo, 2006, 2007; VujČIĆ-Karlo \& Durbešić, 2004). 